\title{
Efficacy of the Application of A Coating Composed of Chitosan and Mentha piperita Essential Oil To Control of Post-Harvest Fungal Pathogens in Tomatoes (Lycopersicum esculentum)
}

Ingrid Conceição Dantas Guerra (I), Rayssa Julliane de Carvalho (I),

Estefânia Fernandes Garcia (I), Marta Suely Madruga (I), Priscila Dinah Lima Oliveira (I), Maria Lúcia da Conceição (I), Evandro Leite de Souza (I)

(I) UFPB - Federal University of Paraíba (Cidade Universitária, s/n - 58051-900 - Castelo Branco, João Pessoa - PB, Brazil)

\section{Resumo}

The use of natural raw materials as antimicrobial agents has aroused the interest of researchers in view of its low toxicity, low amount of harmful effects on the environment and better public acceptance. The film of chitosan in combination with essential oils is presented as a promising alternative in view of its proven antimicrobial activity against some microorganisms. This study evaluated the efficacy of the combined application of chitosan (CHI) and Mentha piperita essential oil (MP) in the inhibition of Aspergillus flavus, Aspergillus niger, Rhizopus stolonifer, Botrytis cinerea and Penicillium expansum on laboratory media and on tomatoes (Lycopersicum esculentum) and its influence on the physical, physicochemical and sensory characteristics of the fruits during storage (25oC, 12 days and 12oC, 24 days). The application of mixtures of different $\mathrm{CHI}$ and MP concentrations (Minimum Inhibitory Concentration e MIC, 1/2 MIC and 1/4 MIC) inhibited the mycelial growth of the test fungi. The application of CHI and MP at sub-inhibitory concentrations (CHI 1/2 MIC and MP 1/4 MIC; CHI 1/2 MIC and MP 1/2 MIC) inhibited spore germination in addition to inhibiting the growth of the assayed fungi strains

\footnotetext{
Referência:

Ingrid Conceição Dantas Guerra, Rayssa Julliane de Carvalho, Estefânia Fernandes Garcia, Marta Suely Madruga, Priscila Dinah Lima Oliveira, Maria Lúcia da Conceição, Evandro Leite de Souza. Efficacy of the Application of A Coating Composed of Chitosan and Mentha piperita Essential Oil To Control of Post-Harvest Fungal Pathogens in Tomatoes (Lycopersicum esculentum). In: Anais do 12을 Congresso Latinoamericano de Microbiologia e Higiene de Alimentos - MICROAL 2014 [= Blucher Food Science Proceedings, num.1, vol.1]. São Paulo: Editora Blucher, 2014.

DOI 10.5151/foodsci-microal-302
} 
in artificially infected tomatoes as well as the autochthonous mycoflora of tomatoes stored at both room and cold temperature. In general, the application of a coating composed of CHI and MP at sub-inhibitory concentrations preserved the quality of tomatoes as measured by their physical and physicochemical attributes, while some of their sensory attributes improved throughout the assessed storage time. These results demonstrate the potential of the combination of $\mathrm{CHI}$ and MP at subinhibitory concentrations to control post-harvest pathogenic fungi in fruits, in particular, in tomatoes.

Palavras-Chave: biocontrol, inhibition, medicinal plants Agência de Fomento: BNB 